\title{
Perspectives Perspectives
}

This section features: (1) reactions of readers to articles and reviews published in the Journal and the replies of authors to whom the comments are addressed (if forthcoming) and (2) viewpoints and opinions expressed in the form of a report, commentary, or interview on issues or topics of current interest.
Cette section sera consacrée à deux types d'articles:

1. La réaction des lecteurs aux articles parus dans la revue et la réponse de leurs auteurs, sìl y a lieu.

2. Les points de vue et les opinions, présentés sous forme de compte rendus, de commentaires, de chroniques ou d'entrevues, sur des sujets d'actualité ou d'intérêt général.

\section{ENGLISH LANGUAGE AND LIFE}

Kathy Bond-Stewart, Harare, Zimbabwe, in conversation with David Cooke, York University, Toronto

Kathy Bond-Stewart is a writer, community organizer and English language teacher who has worked with blacks in poverty-stricken areas of South Africa, her home country, with middle-class young adults in northern Portugal and with former combattants from the liberation war that led to the new independent state of Zimbabwe. She now lives in Harare.

David Cooke teaches English and Education at Glendon College, York University, Toronto. He interviewed Kathy Bond-Stewart in Harare in August 1983 in the course of a two-month lecturing and research visit to Mozambique, Zambia and Zimbabwe.

How do you like to conduct a course or a class in English language teaching? The most important thing for me is maximum participation by students to the point where the teacher almost disappears. This means structuring things beforehand to enable students to take part very actively. It's not freedom to do as you like: It's freedom that calls for great discipline and very hard work. I find if you just allow people to do what they like, it's simply absence of choice. But if you give the students lots of choices, 
stimuli, and guidelines, that really helps them to participate fully.

What sort of things do you do, then, in a class?

I begin with the significance of language by imagining a world without language, and from there we go into the meaning of language and life. After that we look at the meaning of a second language and English as a second language, especially in the context of Southern Africa.

We look at why they learn English. Then we go on to how they want to learn, not only talking about the methods of learning, but values, like creativity, cooperation, critical outlook, energy. Usually I do this as a drawing: It's there to remind us of the values chosen for our group and we try to live them in our time of working together.

Then we look at what they want to learn. Usually I get the content from doing a section on questions, first distinguishing between important questions and trivial questions since about $90 \%$ of education is based on trivial questions. They get the idea by raising important questions they havethose they think about a lot, those they have for me as I teach, those they're very anxious to discuss in their group. From these questions, and others I've collected from over 10 years of teaching and listening to their own unstructured conversation, including in their home language, I've built up a sense of the themes that are really important to them, that they've got really strong feelings about. It's a combination of generative themes and the tools they need to learn English well. That's the content of a course. What's interesting is that I've taught students in very different places: South African black workers, Zulu children, Portuguese middleclass students from quite wealthy families, women ex-combattants in Zimbabwe. And a lot of their basic questions about life are very similar ...

When we talked about the basis of an English language teaching programme, you mentioned "tools" for learning.

Yes, I think it's very important to give people the tools, but link the tools to their basic themes, the things they feel strongly about. I find a lot of grammar books and so on are quite mystifying; they don't actually give people the bare bones of English. Once people have got the basic elements, they can do great things with it. But often the basic structure, which is actually quite simple, is hidden from them in all sorts of mystifying grammar books which are designed to make you go on and on buying them to try and sort out the muddle, whereas in fact, the basic elements of English are quite clear.

How, then, do you like to prepare materials?

One aspect is the themes. Another aspect would be to give people a very clear idea of how English fits together, so for me, structure is important 
and so are functions of language. I've also been very influenced by my own experience of learning Zulu and Portuguese-the things I was anxious to express and things I needed. I think grammar has become very unfashionable and you're not supposed to use it, but in fact, I find if you give some very simple grammatical rules or formula, it really speeds up the whole process. I don't see anything evil about grammar. So I think you must give people a clear sense of the structure of English, functions, ways of saying things that they need to say, but combine it all with generative themes that come from the students themselves.

... one of my most important sources for materials is the work of other students. I find this is the most stimulating factor and students seem to benefit most from reading texts by other students. You can see this in Young Women in the Liberation Struggle ${ }^{1}$ : A lot of that came out by showing one group what other groups had written, and showing Zimbabwean groups what my Portuguese students had written, and so on. This is a great source of stimuli to them: They realize that even students with very little English can write quite exciting things. It gives them tremendous confidence. . .

\section{What is Young Women in the Liberation Struggle about?}

It grew out of another policy of my English teaching, that every group presents a little magazine or booklet at the end of the course-even the group of domestic workers taking literacy-however simple the level. They get a tremendous sense of achievement from having something concrete to show. With my Zimbabwean students, it was particularly interesting since they were young women who were involved in the liberation struggle in various ways. When I was working with them, they were still very scarred by the whole war experience. Some pretended they'd never even joined the struggle. There were huge areas of pain that they didn't want to touch on. A lot of them were very depressed, coming back, expecting a lot, finding very little. Very quickly their whole contribution had been forgotten and they've been rather marginalized.

So writing became almost urgent for them, to explore some of their very painful experiences from the past, trying to situate them within a wider context of life. I collected a lot of their poems and stories, about their past, their present situation, and their ideas about the future. And from about 250 young women over a period of 18 months, I put together this

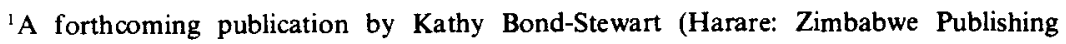
House). 
book which I hope will help people to remember who they are, and also give them encouragement to explore a lot further ....

It seems to me these points raise three interrelated questions for a language teaching course: the general question of the relationship between a student and a teacher, the role of the student, and the role of the teacher. Can you comment on any of these?

It's hard to sort them out because they should be so close. First, a teacher's role should be to provide the kind of environment to release the maximum creativity in the students, and that involves everythinggrammar, literature, drama, conscientization-all the tools I've got at my disposal.

\section{Could you just define conscientization before we go on?}

Well, I see it as helping people to analyse their problems and find ways of overcoming them. So the teacher's role is to provide this creative environment. The definition of the teacher I like best is Socrates', who saw the teacher as a midwife. The teacher is a kind of midwife to bring to birth all that's within the student.

In terms of relationship, I think equality is absolutely essential and that's why I've never taught at a school or even in any formal institution, because I think my sense of equality wouldn't be accepted. I absolutely insist on first names for teacher and student. From the very beginning, I encourage students to probe me in the way I'm probing them: In the session on important questions, there is a section on important questions they have for me as a teacher, and they ask some very difficult questions.

\section{Can you think of any examples?}

Well, "What is your motivation for teaching us?" "Why have you decided to teach us as a group?" "What are you getting out of it?" And then often a lot more personal questions about my past, everything about me. So they're in a very free position to probe me.

Another thing which is very important is that they're free to judge me. This can be a fearful process, I'm sure, to teachers who are not used to it, but it's enormously valuable. So we have constant evaluation through the course, evaluation of classes, and sessions, and then a final evaluation. I think their final evaluation of me and the course is just as valuable as my evaluation of them. I think these are things that make for real equality.

In the beginning, when I was inexperienced in Portugal, some of this was a little bit threatening to me. I mean initially the students react with tremendous enthusiasm and excitement. Then they'd be slightly fearful because they'd exposed so much of themselves that they almost wanted 
to step back a bit. Then after that we'd reach a real state of understanding and intimacy. Now I'm more experienced; I don't have this sense of the student's own insecurity in becoming so open: It's just a very close and satisfying thing. It has led to many long-term relationships and also to many projects outside the classroom ....

What sort of relationships do you like to see between the students themselves in your classes?

That's very exciting. What's so interesting in Zimbabwe is that I was working with a group of 180 Zanla and Zipra comrades from Shona and Ndebele backgrounds who were quite hostile to each other. They started off sitting at opposite ends of the classroom, glaring at each other. Yet their strongest comments in final evaluations were about the unity and deep friendships that developed in the class. Anyone coming to the class would never know who was Shona or Ndebele, who was from Zanu or from Zipra. It was exciting for us all to see the very deep, close friendships and the cooperation that developed in the class. As one student said, "We've got a very big unity and that's lovely."

You've several times now referred to comments by the students. What else did they talk about?

First, the goal of an English course. The goal for me is to help people find their voice. This means helping them become really articulate, creative and critical, helping them develop the confidence to shape their lives. This is important not only with oppressed people who have been silenced by being denied education or a place in decision-making but even with much wealthier students from middle-class backgrounds. In Portugal, I had students from fairly wealthy, comfortable backgrounds, but I found they'd been silenced and oppressed in many ways, and so for them, it was also important to find their voice.

One said, "We were born the children of technology. We lived like clocks, smiling artificially. We lived sucking pleasure like milk through a straw." Another said, "Because I wanted to tell us another life exists and now we're trying to express something of ourselves. We have something real to reveal. And now we're trying to make up our minds about tomorrow, because we believe fervently that we will speak, that we will communicate in a single language, the language of the heart." This is their reaction to learning English. It was their discovery of the world.

Another comment came from the son of a PIDE official-the former secret police. After the coup, a lot of the PIDE were arrested and the families were almost persecuted by the new people in power, so this boy had tremendous complexes. He was completely shunned by the other 
people of his own age and in class he would simply sit in a corner without saying a word. He was totally miserable, and would hide his face. We just accepted him, and I used to smile at him, not pushing him to speak at all. After a month, he suddenly produced some really exciting poems and drawings and became one of the most active members of the whole class. This is what he said, "Every day I understand new things. I make, I create another page of my big and wonderful poem. This is me: a small and strong poet who creates his own part of the world."

Some other Portuguese students from beginners' classes, "Each of us is a world. So each of us has an infinite capacity. Our hands mould the world. We are the sculptors of our lives. To be free is to begin to create. It is to destroy the frontier capacity."

It's very sophisticated language, isn't it?

Well this is the thing. The other exciting thing for me in Portugal was that for the only time in my teaching I had an experimental and control group. I got a class of false beginners from the British Council-students who had done a year or two of English but had to start again. Our textbook was First Things First by Alexander, which other teachers were using with an identical group who had done the same text and were at the same level as my students. At the end of the course, my students were writing some quite sophisticated poetry and stories and had prepared a class magazine called Yes. Meanwhile, the students who had First Things First were still talking about umbrellas and books on the table and blackboards. For me, the excitement of teaching English is that it can change the students' lives and mine, too. 